\title{
Drama as Democratic and Inclusive Practice
}

\author{
Kristine Storsve ${ }^{1}$, Rikke Gürgens Gjærum ${ }^{2 *}$ and Bjørn Rasmussen ${ }^{3}$ \\ ${ }^{1}$ Faculty of Technology, Art and Design, Oslo Metropolitan University and Norwegian University of Science and Technology, Norway \\ ${ }^{2}$ Faculty of Health Sciences, Technology, Art and Design, Arctic University of Norway and Oslo Metropolitan University, Norway \\ ${ }^{3}$ Department of Art and Media Studies, Norwegian University of Science and Technology, Norway
}

Submission: March 28, 2019; Published: April 09, 2019

*Corresponding author: Rikke Gürgens Gjærum, Faculty of Health Sciences, Technology, Art and Design, Arctic University of Norway and Oslo Metropolitan University, Norway

\begin{abstract}
This article examines how a specific drama and theatre work methodology responds to [1] values in adaptive education; inclusion, appreciation, variation, experience, relevance, context, participation. "Democratic and aesthetic space" (2015-2018) is a practice-led research project, and uses drama and theatre work methodology as key research methods. 7th grade students have participated in a "devising theatre" project, where the prominent expression form has been "statues". The application of the statue work, the formation of ideas and the negotiation processes in the project for this study, all seem to respond to and concretize the democratic work methods and a pupil perspective in adaptive education.
\end{abstract}

The statue work and the "devising theatre" project in its entirety contributes to the pupil's understanding of him-/herself, in a context and in interaction with others. The pupils' opportunity to explore aesthetic idioms seems to expand their expression skills, and an exploratory ensemble-based form of learning gives the opportunity to discover their own and the other's "voice". When more people participate in expressing themselves and listening, this opens for the inclusion into a community.

Keywords: Statues; Devising; Ensemble; Adaptive education; Inclusive learning community; Democratic participation art

\section{Drama As Democratic And Inclusive Practice.}

The general section of the national curriculum for primary and lower secondary school states that in the school of the future, pupil-active teaching methods should be used as a form of democratic practice. The curriculum states that "/.../ pupils who learn about and through creative activities develop the ability to express themselves in different ways and to solve problems and ask new questions" (National curriculum 2017, p. 8). The instruction must ensure that democratic values are promoted and contribute towards pupils mastering participation in democratic processes (National curriculum 2017, p. 9 - 13).

Pedagogical researchers [1] emphasize that practical democracy is not just about conversation, but also about interaction. They claim that many pupils prefer this instead of discussions. Ph.D. candidate Gro Lorenzen \& Åse Røthing [2] have, however, investigated how democracy and critical thinking are tied together in school. They find that textbooks offer knowledge of democracy, while the foundation is lacking in order to actively develop democratic practice and critical thinking. This is further supported by the pedagogues Elisabeth Sjøblom, et al. [3] who find that there is not very much variation in work methods in Norwegian school, and that this, among other things, affects pupils' experience of weak academic inclusion.
In other words, research points out that teaching about democracy is not necessarily the same as learning through democratic practice. Based on a collective and aesthetic form of learning, this article will shed light on drama and theatre teaching as a form of democratic practice. This practice will include everyone, instruct children's co-responsibility for their own communicative actions, and teach pupils the courage to express and process their own voices and their knowledge Rasmussen \& Gjærum [4]. The article is part of the research study "Democratic and aesthetic space" (Storsve, 2015-2018), and has a democratic focus on adaptive education.

Adaptive education has been a statutory right in Norwegian primary and lower secondary school since 1975 and combined with the concept of equal education NOU [5], this right is close to a democratic ideal. Equal education accommodates both the individual and the community and should be able to be carried out with varied methods based on an understanding of learning as a social process NOU [5]. We consider equality and inclusion to be part of the school's democratic mandate and will in this study examine how a specific drama and theatre work methodology responds to the following values in adaptive education; inclusion, appreciation, variation, experience, relevance, context, participation Håstein \& Werner [1]. 


\section{Research Design}

The sub study of this research article on adaptive education and democratic learning form is part of a doctoral project called "Democratic and aesthetic space" (Storsve, 2015-2018) , which is linked to the national research initiative "Drama - Theatre Democracy" (2014-17) . As a basis for studying drama and theatre work methods in primary and lower secondary school in a democratic perspective, a "devising theatre" project was planned and implemented for the pupils. Data material has been produced from two fieldwork projects on drama and theatre methodology in the 7th grade of primary school; one fieldwork project in a small village in eastern Norway (21 pupils) and one fieldwork project in a medium-sized city in northern Norway (22 pupils) .

The data consists of a total of 7 hours of video documentation, 35 school hours with participatory observation and 42 pupil interviews and generates knowledge in a triangulated whole. This involves the creative and interpretive work the researcher carries out: "/.../ between practice, the critical context that frames the practice, the theory studies and the framework for the research work" Ulvund [6]. The fieldwork is planned and carried out by a trained drama teacher with over 20 years of experience. The drama teacher was not part of the college at any of the schools and did not know the pupils. The fieldwork took place during one week at each of the sites.

The doctoral degree project is placed in an art-based and performative research paradigm Haseman \& Leavy $[7,8]$ which is a "practice-led" research paradigm in which drama and theatre work methods can be used to generate research questions and produce data material. Here the pupil's as well as the researcher's critical reflection practice is central to the design: "In this work, the self-reflexivity and the introduction of perspectives that 'expand horizons' are crucial in both the artdidactic and research-related context" Rasmussen [9].

In other words, drama and theatre forms of work in interaction with critical reflection are both learning tools and research tools. The project's design and goals are also closely related to action research, because the research involves learning in and through practice and reflection; it generates knowledge in and for practice. McNiff [10] Knowledge for practice means a goal focused on contribution to change and the addition of new practices in school. The following clarifies how drama didactic work forms also generate qualitative data.

\section{Applied drama and theatre methods in learning and research practice}

Both fieldwork projects started with initial basic training exercises. Briefly outlined, this deals with collective sensory training exercises that train the participants' concentration and attention towards each other. It involves being able to imagine and try out the physical part of "playing a role" and gaining experience with basic improvisation skills. Selected basic training exercises are intended to give the pupils experience with some of the tools and instruments of the drama discipline and give common experiences as a starting point for the further creation of their own stage expressions.

The exercises also serve as reflexive expressions and provide the drama teacher as a researcher insight into the pupils' insights, attitudes and social relationships. The drama teacher acts as supervisor, facilitator, project manager and researcher, controlling the project through what we here may describe as three phases: "the brainstorming phase", "the production phase" and "the assembly phase." In the "brainstorming phase", the goal is to generate ideas and contributions from everyone in the group, without any guiding principles as the starting point. There are, among other things, ideas written on notes that are added anonymously in a box and ideas are put together and further developed in groups on large sheets. The activities varied from individual work to group and plenary class situations.

The pupils expressed themselves, listened, argued and made choices. Physical collaboration in a playful, permissive climate provides the researcher with valuable insights and documentation for the interpretation of the individual, the class and democratic values in play. Following the chosen theme, the pupils continue in the "production phase" with input and suggestions for e.g. roles, scenes, text, music, costumes and scenography. Here the pupils' input and suggestions were further developed into a stage idiom. In this formative process, new knowledge emerges for the researcher, including a self-reflective insight into what is the pupil's, and what is the teacher's, contribution to the progression of form and insights.

In the last phase called the "assembly phase", the pupils tried out how what they had produced worked together as a stage expression. It is "probationary time", and the pupils adjusted, changed, agreed and tried again. Here, the director's inputs in the form of transitions between scenes, such as the use of music, props, entries/exits and timing will be determined. In this phase, the researcher generates data relating to, among other things, differences in opinion, collaborative skills, leadership and consensus negotiation. The drama educational project ultimately led to a performance for the other pupils on the same grade level.

For the sake of analytical delimitation, we will mainly focus on one didactic section; "the statue work" as an aesthetic learning form. It is a form of work inspired by Augusto Boal's theatre practice and has gained widespread pedagogical application Boal, Engelstad \& Sæbø [11-13]. Three types of statutory work were mainly used in the course of the project; 1 . Group-wise "theme statue", 2. "red light" statues and 3. "3 pictures". The "theme statue" focuses on the pupils' expression of thematic and conceptual understanding in bodily "freeze positions".

The drama teacher gave the pupils the task of making a statue based on the concept "family" and then based on the concept "freedom". The terms "family" and "freedom" are translated into 
concrete themes that pupils can relate to. This includes concrete expressions of emotional relationships with family members, forms of fellowship, events and symbols of freedom. In the "red light" statues spontaneous, dynamic situations occur that pupils in an observer role would interpret, and further assign "roles" and "lines" to those who formed the "statue". It stimulates the pupil as co-poet and interpreter, and this in turn provides the researcher with meta-interpretation data.

"Red light" was also used as a framework for the pupil to be able to model fellow pupils as a statue. This took place without guidelines on themes. This resulted in a "slideshow". By letting several statues arise one after the other, as in a "slide show", a possible dramaturgical course of action is made visible. Here, too, replicas were produced through the technique of "thought bubbles", the purpose of which is to open the pupil's creative power through interpretations of the statue.

The third statue form, "3 pictures", was the contribution to "series of images" as input to important/central scenes in connection with a planned theatre production. Each view also led to reflective conversations about interpretation, the importance of the choices and the assessment of the proposals of the groups. During this phase, theme choices and the dissemination of topics were intensified, and the pupils demonstrated and practiced academic and social skills. The methods also generate knowledge for everyone involved and produce artistic material for the pupils' stage displays.

Both in the work on "theme statues", "red light" and "3 pictures", the pupils have experiences as actors and observers of their own actions, forms of expression and interaction. In interaction with the drama teacher, the pupils reflect on what is being created and what they interpret. Through these reflections a data material is generated that can shed light on adaptive education, also via a democratic perspective. The data was secured and complemented through video recordings, participant observation, reflection discussions, researcher's journal and interviews. Work methods in drama and theatre and art-based research methods are temporary and volatile. Video documentation and records complement the methodological approach and strengthen the foundation for qualitatively examining the way in which pupils participate, express themselves and listen with body and voice in creative interaction.

\section{The Basic Values Of Adaptive Education}

From pedagogical research on democratic forms of work, we can also find frameworks for adaptive education. The preservation of the pupil's perspective is, according to Håstein and Werner [1], a basic value and they furthermore find 7 other values that relate to adaptive education: inclusion, appreciation, variation, experience, relevance, context, participation [1]. The values are linked to activity within the framework of a community. Pupils learn in an inclusive community and benefit from the education. The education will be characterized by both variation and stability.
The pupils will be able to use their own experiences, expertise and potential. The pupils must experience being challenged, but also have the opportunity to succeed. What pupils meet in school should be relevant here and now, but also in their future. Appreciation focuses on how activities should mean that everyone is met with positive expectations. The pupils should feel appreciated both by the school and their fellow pupils. Furthermore, the pupils must experience a context between the different parts of the education. The pupils' opportunity for participation is also central to adaptive education and deals with both planning, implementation and assessment of school work Håstein \& Werner [1].

Inclusion is about the individual's right, independent and unique voice interacting with the others, and where the best and welfare of the community can also play a central role Pettervold, Stray [14,15]. Participation is further linked to dialogical interaction as we find it described in Olga Dysthe's, et al. [16] research. The foundation is the basic "I - You" relationship Buber [17], which involves recognition and appreciation of each other. We also pursue such values into the art didactic research of the theatre.

Drama researcher Mia Perry [18], for instance studied how theatre as bodily exploratory work method includes more people in a creative community and how the "self-made" forms help contributes towards greater participation than more traditional "dramatizations" in school. Perry points to emotional, sensory and relational factors that arise when pupils work on creating an exploratory stage expression. Perry claims that the bodily improvisation complements the verbal discussion traditionally dominant. Thus, more become participants in the creative work than those who are strong verbally.

Perry also points to the value of "ensemble" work. Jonothan Neelands [19] is concerned with the theatre ensemble as a democratic form of work, and how an ensemble unites the social and the artistic. To learn through drama in the ensemble is learning based on "the negotiating and continual re-negotiating of the 'laws' in the learning group" [19]. Relational forms of work, improvisational and exploratory interaction, contribute, therefore, to social interaction competence and to artistically exploratory expertise. In the further analysis, we will associate the mentioned values with the learning forms of the drama and theatre subject by applying them here as categories to interpret the fieldwork.

\section{Aesthetic Forms Of Learning And Adaptive Education}

\section{Inclusion}

Pupils lie, sit and stand in different positions. They move themselves and each other, point and explain, listen to and look at input. They keep trying until they find an expression for their statue, which is then shown to the other pupils (transcribed video, 16.11.2015). There is a lot of activity in the classroom as the pupils are in full swing making freeze pictures of two themes: 
"the family" and "freedom." When the pupils after the project had ended were asked what in their experience worked best as a working method, Marit responded: "/.../ those sculptures, /.../ Then it was a lot of cooperation, like a big mess ... so then everyone had to think. Show what they meant" (Marit, 12 years old, field 2). Line also emphasises the statue work.

when we talk about collaboration: /.../ That thing with those statues, when you clapped, and with the thought bubbles /.../ hear what they want and what the others say /.../ Also what we say. Then I feel that you are being heard, and that one can listen to the others (Line, 12 years old, field 2). In the work with statues we see how the pupils' collective inclusion and subjectively perceived interaction are expressed.

Jørgen says about the collaboration: for example, a person said an idea /.../ showed the others how they should stand, without just talking, standing up and showing the movement /.../ I did it the same way when I came up with an idea /.../ (Jørgen, 12 years old, field 2). Using the body in learning activities provides Jørgen with new opportunities when he interacts with and includes his fellow pupils. The verbal and bodily elements complement each other in the learning situation. The drama teacher observed that the pupils gave and took their place in the work of making the statue, and through it they listened and expressed themselves in an inclusive community.

The intention is to accept and confirm each other as people, and it has to do with relational dialogue comprehension [17]. The acknowledgment the pupils describe illuminates the qualitative encounter when she/he discovers and concretises her/his own comprehension as an "I" - an individual. This occurs in the encounter with the other, a "You", which mutually confirms the other's existence.

Alexandra suggests the democratic potential when she says: If some came up with not so much ideas and the rest came up with quite a lot of ideas, then those who came up with plenty of ideas [helped] in a way the others to find ideas /.../ then they came up with various other details about what they can do (Alexandra, 12 years old, field 1). Here it is revealed how the dialogue functioned inclusively in such a way that more people participated in the creative work. Alexandra points out how the pupils help each other by building on each other's ideas and including details so that everyone gets ownership of the idea development. Dysthe et al. expand upon this as "/.../ the response of the other is the activating principle that creates understanding" [16].

Different perspectives are produced on the same theme, which allows for reflective interpretation. For example, Sara thought that children in "family statues" looked sad, while Sievert thought that the "kids" were using mobile phones, or when a group gave a display of neglect in their family statue and another group an idyllic family portrait. More interpretations and perspectives are included. Through the statue work we find a concretisation of what [1] define as inclusion in the pupil perspective in adaptive education. Inclusion refers to cognitions that arise in bodily interpretations and interactions. The emotional, the sensory and the relational become explicit and open also for the inclusion of multiple perspectives.

\section{Appreciation}

In the interview, Sigurd reflected on which strategies worked to both be heard and to listen to others:

I think people were pretty good at listening to me. Don't know if I did well enough listening to others, but [...] I think I got better at listening after a while [...] maybe I realized others might have some opinions, not just me (Sigurd, 12 years old, field 1).

What Sigurd describes entails what we describe as a gradually matured understanding of appreciation of "the other", which in this case is the fellow pupil. Learning in a drama-pedagogical community is often about room for differing opinions, so that the individual can discover the other, and experience collaboration $[19,20]$. Elise related how she: "/.../ probably learned a bit about how one has to think a little about what the others think and do also /.../" (Elise, 12 years old, field 1).

Emil's reflection specifies how he sees his fellow pupils in light of the interaction in the project:/.../ That you get closer to others, /.../ you might find out more about them. And maybe you want to be with them several times, since you've become more familiar with them through exercises. For I didn't think the people I was in a group with were so interesting, but maybe they were anyway (Emil, 12 years old, field 2).

Emil and the other pupils worked closely together in the "you and me" relation in the drama work. Pupils discover themselves as well as the other in an inclusive learning community. It also means that the class, or "ensemble" in drama and theatre processes, can unite the social and the artistic, as Neelands points out [19]. Katja also appreciates herself and others through the interaction: "To actually dare to stand before all the others and dance. To be able to stage a small play with the others and get to actually create an idea with the others /.../" (Katja, 12 years old, field 2). Katja sees herself here as a person who can contribute both with dancing and creating plays. The work form creates room for interaction and perspective change.

Emotional, sensory factors are in play, in the work of creating an exploratory stage expression, and this offers relational learning: "/.../ that one has seen sides of others, which one did not think they had, how funny they are, and such things" (Sølvi, 12 years old, field 2). Sølvi has seen, but Theo also points out the value of being seen: "I think they started to respect me more, because I had many suggestions on what could happen" (Theo, 12 years old, field 1 ).

The form of education contributes to the pupils' experience of "/.../ knowing the feeling of being valued based on who they are"[1]. The creative work with statues and creating performances contributes towards letting pupils see their fellow pupils in ways other than the social roles established in 
the classroom. In this project, bodily cognitive forms and the making of content and form without a facade help open the pupils to viewing both themselves and others as valuable in the community and supporting democratic interaction.

\section{Variation}

The teacher as well as the researcher observed that several of the girls who usually behaved quietly and modestly in the background participated actively in solving the task of creating different tableaux for the "slide show" (Reflection conversation teacher, field 1, 18.09.2015). The methods of image theatre and statue work are known to do just that; offering a voice for those who cannot, will not or usually do not manage to express themselves orally $[11,12]$. More pupils are given the opportunity to express themselves through a varied idiom, and more pupils are given the opportunity to discover other pupils' "voices" and suggestions into the community.

In "3 pictures" (Phase 1 and 2), the assignment was about presenting proposals for the theatre performance by groupwise creating statues that displayed characters, place and event. The viewing of the statues served as a visual expression and the reflection conversation served as oral interpretations: "It was quite funny, because there were quite a few who had thought differently, for example that it was a coronation. We hadn't decided that before anyone came up with it, in a way. So, it was very smart" (Janne, 12 years old, field 1). The reflexive conversation, which followed every viewing, served as a concretization of who it was about, what happened and where the action took place, as the princess coronation scene indicates.

The statue work concretises and makes visible various options for action. We find that the pupils gradually become more participant, defining and concretizing roles, relationships, actions and places. They focus on costume, props and sound/ music. Through the creation and presentation of their proposals, more pupils became active in co-creating common content and form. For the pupils, the viewing also serves as a way of expressing themselves in a varied manner and listening to different suggestions.

Through " 3 pictures" (Phases 1 and 2), the pupils participate in several varied forms of work by drawing up ideas, such as pictures in a cartoon, and/or writing ideas for the course of action on paper/blackboard. They must discuss and try out the ideas, create statues and display to each other. Such variation provides room for the "polyvocality" that Dysthe et al. [16] encourage. The exploratory (devising) strategy which is employed not only facilitates variation, but also enables pupils to vary their approach within the inclusive learning community.

Håstein and Werner emphasize: "If variation is employed in many ways, it is more likely that many pupils may regularly have the experience of working on something that suits them"[1]. In the statue work " 3 pictures", the pupils relate to bodily utterances, sensory and emotional relationships in action and interpretation. The statues as a turning point expand the pupils' own expression skills. Variation thus also relates to opportunities for ambiguous and nuanced content.

\section{Relevance}

During the discussion about various stage choices for the performance; a crime story (field 1), one of the pupils raises the hand and asks: "Why must the princess die? - Must she die?" The question is asked to the group, and it is an important question, and almost everyone joins in the subsequent discussion. It is about relevance, ownership and motivation. Right there and then it is absolutely essential that the drama teacher provides opportunity for all pupils to participate. It is about safeguarding and consolidating the pupil's experience of actively participating, and that their opinion matters.

The research diary states: "Virtually everybody got up on their own initiative. We got to point out nuances and possibilities. Heard each other's arguments and views" (Researcher's journal, field 1, 10.09.2015). Video recordings show that time is allotted to let everyone contribute with their input. The pupils express themselves, they argue and listen to each other's opinions. The pupils find that the choice is important and that much is at stake. The engagement is directly related to the fiction: "/.../ it was a bit of an important act, you know.

That the Princess died or was injured" (Siri, 12 years old, field 1), Siri believes, which Anne also points out: “/.../ because it was a very important part of the play, and then they wanted to /.../ have their opinion to be part of the play then too" (Anne, 12 years old, field 1). Thus, this points to two significant factors related to relevance; the drama teacher's role and the pupil's experience. The drama teacher seeks relevance by pursuing the pupil's interests and choices and facilitates plenary talks at which everyone is engaged and involved. The other relationship affects the importance of the pupils experiencing the theme to be relevant to them in the current situation, as in this case by ownership of the idea design. Håstein and Werner associate the value relevance in adaptive education to "what the pupils meet in school should be relevant to their present and future"[1]. Such relevance must be understood beyond what concerns the content of the subject matter. It also relates to the perceived relevance, which here is linked to the pupils' involvement and learning about the theatre they have created, its themes and idioms.

From the fiction universe, which in the present context is the "crime story", the pupils comment on what they think is relevant. Vilde states: "Something exciting has to happen /.../" (Vilde, 12 years old, field 1), and Petter supplements: "/.../ because it was the end and they want the end to be as good as possible" (Petter, 12 years old, field 1). Differing opinions are part of this process and cause someone to see the matter from a different perspective, as Siri states: "/.../ I thought maybe, like 'Theo' said, that perhaps not everybody liked it. That the Princess died"(Siri, 12 years, field 1 ). 
Another pupil reflected on those who changed their mind: "Perhaps there was someone who agreed with him, so when he first said it / ... / then there was at least another who had the same opinion" (Mina, 12 years old, field1). The pupils decide in the drama work "small and large" based on something that is relevant to them and thus relevant to the drama teacher. This emphasizes that aesthetic forms of expression, such as the statue work and the creation of fiction, are socially relevant, and act as the hub of active participation and learning. In an adaptive education perspective, relevance arises in the pupil's encounter with his/her own involvement and differences of opinion in the community.

\section{Experience}

Even though the pupils participated actively in e.g discussions, drawing and physical testing, the data shows that the tasks can be demanding:

"/.../ someone managed to grasp and solve the task in slightly different ways, such as writing lists/points on the blackboard then create statues. Others solved the task more directly on the floor, but also through drawing /.../" (Researcher's journal, field $1,10.09 .2015$ ).

Different possibilities for solving the problems affect interaction and give the work a degree of unpredictability. One pupil started to get a little frustrated because he wasn't in control like he was used to. The research diary states: "This is a positive and participating pupil, but who likes to have control" (Researcher's journal, field 1, 10.09.2015). The need for input from the teacher was evident when he and the other team members broke up several times to speak to the drama teacher or class contact teacher. It was important to "stay in the game", try something, do things differently as they went along and relating to not having to find a correct answer.

The pupil who experienced frustration, but who also did not give up, put this experience into words: "That we succeeded, that we were able to go through with it /.../ That it is often possible to find a solution when it seems that there is not going to be a solution" (Sigurd, 12 years old, field 1). For Sigurd, and others like him, it was important to experience that they were successful in completing a stage display. This is about experiences with resistance and frustration, which nevertheless end in mastery. The importance of experiencing mastery with a final product the pupils have created themselves is emphasized by Tiril: "It was perhaps the work at the end, where we got to try out everything we had practiced, to make a play, so that was very good" (Tiril, 12 years old, field 2). Tiril touches upon the value of using experience, gaining experience and to be challenged in the classroom.

These are the values that Håstein and Werner point out in connection with adaptive education: "The pupils' experiences, expertise and potential will be put to use and challenged in the classroom, and they will be given the opportunity to succeed"[1]. The pupils are challenged, through the statue work and in their own creation of a stage performance, to create something for themselves that does not have a correct answer. The representation of the body provides other possibilities for suggestions, the use and appropriation of experience: "When you use the body, [you] are not as afraid of making mistakes as when you talk. When I use the body, I am not so afraid of making mistakes, because it is a little easier to correct" (Berit, 12 years old, field 2).

Berit expresses a positive experience with the use of bodily expression. The drama work with statues and body therefore appears to some pupils to work in a strengthening way regarding familiarity with daring to express themselves. There is no "correct answer" in bodily expressions. One cannot say the wrong answer, but one can show what one understands and feels. One can be seen and respected, experience mastery and experience that what each individual pupil expresses is significant. The pupils' own experiences are both safeguarded and challenged. Particularly, it applies to experiences of being in the uncertain, not having the correct answer, there is no correct path to the goal and the pupils must deal with several possibilities.

The drama teacher must also "be committed", let the pupils be e.g. frustrated and not solve the tasks for them. Here we can also highlight the vulnerability of this project form, because there is genuine risk that one will not succeed. Although success in dealing with uncertainty and risk are also important experiences, experiencing success, as the pupils in this project did, may sometimes be absolutely crucial, according to[1]. Thus, the significance of the drama teacher, in the interaction with the pupil's experiences through democratic practice, is realized through exploratory ensemble forms of learning.

\section{Context}

Experiencing the context or coherence of the instruction is a central element of adaptive education [1]. When we looked at each other's "theme statues" based on the concept "freedom" in the "sculpture park", the pupils reflected on religion:

Several [statues] had prayer as a theme - we could talk about religious freedom and the personal freedom to pray. We saw statues of 'The Statue of Liberty' and 'the beggar's cup and the giver' /.../ (Researcher's journal, field 1, 08.09.2015).

Various representations of the concept of "freedom" provide multiple interpretations, and reflection deepened through interactions: "We interviewed the statue - and they thought about the idea of giving and receiving money to get out of poverty" (Researcher's journal, field 1, 08.09.2015). This form of work helps to interpret meaning content in a way that offers context and nuances. It is not, of course, a given in everyday life where one is flooded with impressions: "[I] think of what the statue actually says, because when I see statues I think 'Oh, look at the nice statue' and then I move on" (Magnus, 12 years old, field 2). Facilitated interpretation of and reflection on what the 
varied stagings and "statues" can tell us will generate a content of meaning in which the pupil seeks and finds experiences of coherence and differences.

When pupils involve their own inner world, they draw insights from many subjects and arenas. This facilitates transfer value and refers to another form of coherence in learning. In the pupil interviews, the English classes, the Norwegian classes or the music classes, for example, were mentioned. Alexandra's words: "/.../ subjects in school, like Norwegian, making a story yourself /.../" (Alexandra, 12 years old, field 1). Tone reflects on how she personally can transfer experience in school work: "Well, in the English classes we often use acting, but then it has already been written how to do it [...]. But I do believe that after what we have done here, [I] am not afraid to express more ideas" (Tone, 12 years old, field 2).

The data material shows us that the form of work builds a connection between teaching material and the personal self, while simultaneously building insights on relationships between form of expression and formation of opinion. Bodily recognition through the statue work here expands the understanding of relationships. The pupils understand themselves in a context and experience how they can create coherence themselves.

\section{Participation}

In the democratic perspective of the research project, the pupils' participation is crucial. The pupils' ideas, suggestions and choices about the performance they have created themselves have been in focus both when the project's forms of learning were chosen and in the implementation of the forms of learning. Siri says: "Yes, when we had those family pictures (statues). That we could show what we were thinking, show with pictures" (Siri, 12 years old, field 1 ).

Siri points to her real involvement, thereby confirming an important premise for adaptive education: "most pupils can grow from having the opportunity to participate in their own everyday life."[1]. Participation is manifested in this study not only as verbal statements, but also as non-verbal utterances adapted to bodily, physical proficiencies, something Adrian's experience tells us: "Slides /.../ more enjoyable and better /.../ I remember coming up with ideas for facial expressions" (Adrian, 12 years old, field 1). For him, the contribution to facial expressions became something significant.

Adrian participates in a quite subdued manner and with little mimicry in most situations, but in the video recordings we see that in his work with the "red light" statues, he each constantly adds physical expressions, both through facial mimicry and the "thumbs up" in various "freeze positions" (Transcribed video footage, field 1, 07.09.2015).

Participation also occurs in the decision-making processes where the pupils themselves decide what to do. This applies both by majority decisions through voting and decisions through the power of argumentation and consensus. Such processes put democratic processes into play and provide the community with participation competency and self-awareness. One method of facilitating participation was to put ideas and suggestions in a box, so everyone got to contribute their own input independently of the wants and wishes of others. This is positively perceived by several: "/.../ Yes, I think it was good, that we could write a note and submit what we thought /.../ because then everyone got to state their opinion" (Viktor, 12 years old, field 1).

The fact that everyone is given the opportunity to voice their opinion is central to experiencing that one as an individual is participating in the process. At the same time, it is a "low threshold" form of participation, where one does not risk speaking out verbally in plenary situations. The pupils would vote on suggestions for the performance, write the alternatives on the board and summarize what suggestions got the most votes. There is an atmosphere of understanding that the majority makes the decision, and that it is fair: "Well, it was the settled in a very fair manner, with those there were the most of and stuff / ... / and that's enough for me /... /" (Katrine, 12 years old, field 1).

Katrine expresses that she is satisfied with the way in which the choices were made, while at the same time one may argue that she probably does not have knowledge of other ways to decide the vote in such a context. It becomes clear that it is difficult to assess what is democratic. When the concern of those who must "let go of their ideas" is drawn into the discussion, somebody suggests mixing ideas together. (Transcribed video recording, field 1, 08.09.2015). The pupils strive for all to be heard, for everyone in one way or another to have some of their ideas and input included, and thus achieve co-ownership. Here the pupils introduce a form of compromise.

Sølvi focused on this: "/.../ In a way we put everything together, and then we tried to think of one thing for everything /.../ and see if they had any meaning together" (Sølvi, 12 years old, field 2). Sølvi looks simultaneously for a connection or common meaning, and accordingly it is not simply about putting the parts together. On the one hand, it may be perceived that the pupils choose a compromise to avoid disagreements and that the contributions must be equally distributed. On the other hand, the work to strive for everyone to be heard, and to look for common meaning, is both time-consuming and challenging.

Points out the value of a pedagogical practice where children and adults interact: The way to participate is more complex and demanding, but at the same time the opportunities are great for the children to have ample opportunity to experience what it means to be a democratic participant in the form of taking initiative and listening to others, and they can experience that there is no correct answer. The children can gain experience in participating in different communities in which it is positively binding to participate [14].

In other words, participation relates to several levels, from personal experience of participation to a more formal level (e.g. exercising the right to vote) which relates to having an impact on 
how elections should be carried out. In this project, participation and choice dealt with what content and form of expression the pupils wanted to convey. This study facilitates "bodily experiences" of democratic participation. The pupils negotiate both over how to make choices, and what they should make a performance about. They find solutions for and through bodily forms of expression for their stage ideas and suggestions. This provides the individual pupil's contributions with significance and gives the pupils real experience in participation.

\section{Adaptive education and inclusive learning community}

The data material shows that statues, ensemble work and creating theatre performances touch on several aspects of adaptive education and an inclusive, democratic learning community. The application of the statue work, the formation of ideas and the negotiation processes in the project for this study, all seem to respond to and concretize the democratic work methods and a pupil perspective which [1] are concerned with in adaptive education. We have investigated how a specific academic drama and theatre work methodology responds to the following values in adaptive education; inclusion, appreciation, variation, experience, relevance, context, participation.

The analysis points to an art-pedagogical operationalization of these key criteria for adaptive education. The operationalization is particularly visible when e.g. Line experiences that she both listens and is listened to in the work on "red light" statues, or when Sigurd realizes that others, too, have opinions worth listening to. In such cases, the pupils include each other and appreciate each other in the statue work, the idea development and the negotiation over selected solutions. The pupils experience varied approaches to creating a performance, something Janne discovers in the work with, among other things, "3 pictures".

Both as actors and observers, the pupils participate by adopting different perspectives in the work with statues. The study finally shows how connection is operationalized and made concrete for the pupils when, for example, Magnus reflects on interpretations of the statues in the "sculpture park". We also see how relevance is activated in the involvement with the pupils' own "crime story". Bodily recognition and the interaction between the individual and the community mobilize multiple facets in the pupils. Emotional, sensory and relational connections are affected and challenged throughout the statue work and the "devising theatre" project in its entirety. It contributes to the pupil's understanding of him-/herself, in a context and in interaction with others. The pupils' opportunity to explore aesthetic idioms seems to expand their expression skills.

When more people participate in expressing themselves and listening, this opens for the inclusion into a community. Drama and theatre pedagogical teaching forms, such as we have seen here through the statue work, stand out in this project as an exploratory ensemble-based form of learning in which pupils were given the opportunity to express themselves through another idiom, and the opportunity to discover their own and the other's "voice".

At the same time, an exploratory ensemble learning form is demanding. Pupils with special needs will require further adjustments. Already established power structures in the classroom will be more or less visible and may lead to some pupils' input still being given priority. Furthermore, when there are no correct answers to be presented, it is required that the drama teacher masters a playful openness, as offered by the procedures and learning forms. She must be able to facilitate openness and real opportunities in the democratic interaction. This may not always be easy and requires great pedagogical routine.

The study shows that under certain circumstances, the use of drama and theatre with primary and lower secondary school pupils establishes an inclusive learning community. The aesthetical approach appears to be close to an operationalization of values derived for adaptive education. Meanwhile, professional expertise, experience, time and space are essential to the preparation and implementation of such projects. In other words, this study prompts new positions on aesthetic and exploratory ensemble learning forms in schools [21-26].

\section{References}

1. Håstein H, Werner S (2014) Tilpasset opplæring i fellesskapets skole. In: Bunting M (Edt.), Tilpasset opplæring-i forskning og praksis. pp. 19-55.

2. Lorentzen G, Røthing Å (2017) Demokrati og kritisk tenkning i lærebøker. Norsk pedagogisk tidsskrift 2: 119-130.

3. Olsen MH, Mathisen ARP, Sjøblom E, (2016) Faglig inkludert? Fortellinger fra elever med ulik måloppnåelse.

4. Gjærum, Rikke G, Rasmussen B (2017) Fagovergripende diskurs: en fremtid for kunstfagene i norsk skole. Norsk pedagogisk tidsskrift 2: 192-196.

5. (2014) Elevenes læring i fremtidens skole.

6. Ulvund M (2012) Ekkoteater-praksisledet forskning innenfor et performativt paradigme. In: Gjærum RG, B Rasmussen (Edt.), Forestilling, framføring, forskning. Metodologi i anvendt teaterforskning. pp. 51-75.

7. Haseman B (2006) A Manifesto for Performative Research. Media International Australia incorporating Culture and Policy, theme issue “Practice-led Research", 118(1): 98-106.

8. Leavy P (2017) Arts-based research design. In P. Leavy (Edt.), Research Design. pp. 191-223.

9. Rasmussen B (2013) Teater som danning- i pragmatisk-estetiske rammer. Heggstad IKM, Eriksson SA, Rasmussen B (Edt.), Teater som danning. pp. 21-36.

10. McNiff J (2013) Action Research: Principles and Practice. New York, UK.

11. Boal A (2002) Games for Actors and Non-Actors. London: Routledge, UK.

12. Engelstad A (1989) De undertryktes teater. Når tilskueren blir deltaker. Augusto Boals metoder og praksis. Oslo: Cappelens Forlag, UK.

13. Sæbø AB (2016) Drama som læringsform. Oslo: Universitetsforlaget, UK. 
14. Pettersvold M (2014) Demokratiforståelser og barns demokratiske deltakelse i barnehagen. Nordic Studies in Education, 34: 127-147.

15. Stray JH (2011) Demokrati på timeplanen. Bergen: Fagbokforlaget, UK.

16. Dysthe O, Bernhardt N, Esbjørn L (2012) Dialogbasert undervisning. Kunstmuseet som læringsrom.

17. Buber M (1923/2003) Jeg og Du. Med et innledende essay av Terje G. Simonsen. Oslo: De norske Bokklubbenes utgivelse, UK.

18. Perry M (2013) Devising Theatre and Consenting Bodies in the Classroom. In D. Masny (Edt.), Cartographies of Becoming in Education-A Deleuze-Guattari Perspective pp. 93-108.

19. Neelands J (2009) Acting together: ensemble as a democratic process in art and life. Research in Drama Education: The Journal of Applied Theatre and Performance, 14(2): 173-189.

20. Sæb $\varnothing$, Aud Berggraf (2015) Drama-an inclusive form of teaching and learning. New Zealand journal of research in performing arts and education, 5: 1-12.
21. Govan E, Nicholsen H, Normington K (2007) Making a Performance: Devising Histories and Contemporary Practices. Oxon: Routledge.

22. Heddon D, Milling J (2006) Devising Performance-a critical history. Palgrave Macmillan, UK

23. Johnstone K (2007) IMPRO-Improvisation and the Theatre. London: Methuen Drama, UK.

24. Kunnskapsdepartementet (2017) Overordnet del-verdier og prinsipper for grunnopplæringen. Retrieved from p. 1-19.

25. Oddey A (1994) Devising Theatre. A practical and theoretical handbook. London: Routledge, UK.

26. Young IM (2000) Inclusion and democracy. Oxford: Oxford University Press, UK.
This work is licensed under Creative Commons Attribution 4.0 License DOI: 10.19080/GJIDD.2019.06.555690

\section{Your next submission with Juniper Publishers will reach you the below assets}

- Quality Editorial service

- Swift Peer Review

- Reprints availability

- E-prints Service

- Manuscript Podcast for convenient understanding

- Global attainment for your research

- Manuscript accessibility in different formats

( Pdf, E-pub, Full Text, Audio)

- Unceasing customer service

Track the below URL for one-step submission https://juniperpublishers.com/online-submission.php 